\title{
OCENA WYBRANYCH ELEMENTÓW PROGRAMU KSZTAKCENIA Z ZAKRESU RACHUNKOWOŚCI NA DWÓCH UCZELNIACH PUBLICZNYCH W POLSCE
}

\author{
ASSESSMENT OF SELECTED ELEMENTS OF EDUCATION PROGRAM WITHIN \\ THE SCOPE OF ACCOUNTING ON TWO PUBLIC UNIVERSITIES IN POLAND
}

Business Accounting Office Sp. z o.o.

ul. Cyfrowa 6, 71-441 Szczecin, e-mail: malwina.mieczkowska@busacco.com

*Katedra Ekonomii i Rachunkowości, Zachodniopomorski Uniwersytet Technologiczny w Szczecinie ul. Żołnierska 47, 71-210 Szczecin, e-mail: bnadolna@zut.edu.pl

\begin{abstract}
Summary. Professions related to accounting can be included in the professions of the future. Demand for employees with developed competences in this field is still at a high level. These professions require professional knowledge and specific skills that an adept of the accounting can also acquire at the university. Currently, many universities, especially economics, in their educational offer have educational programs containing numerous subjects in the field of accounting. The basic aim of the article is to compare selected elements of education programs in the field of accounting between the educational offer of two public universities in Poland.The first part of the article compares the learning outcomes achieved on the major and specialty subjects in the field of accounting carried out at the University of Economics in Poznan and the State Higher School in Głogów. The analysis covered the forms of knowledge transfer, the number of hours per subject and the obtained learning outcomes in the form of knowledge and skills. A separate section has been devoted to the comparison of social competences possible to be obtained by students, which are declared in the syllabus of the analyzed universities. In the theoretical part of the article, descriptive methods were used, while in the research part a case study was used.
\end{abstract}

Słowa kluczowe: programy studiów, efekty kształcenia, rachunkowość, uczelnie.

Key word: educations programs, educational outcomes, accounting, university.

\section{WSTĘP}

Zawody związane z rachunkowością można zaliczyć do zawodów przyszłości. Zapotrzebowanie na pracowników o rozwiniętych kompetencjach w tej dziedzinie utrzymuje się ciągle na wysokim poziomie. W zawodach tych wymagana jest profesjonalna wiedza oraz konkretne umiejętności, które adept sztuki księgowej może nabyć również na uczelni. Obecnie wiele uczelni, szczególnie ekonomicznych, w swojej ofercie edukacyjnej ma programy kształcenia zawierające liczne przedmioty z zakresu rachunkowości. Ze względu jednak na coraz większe i zróżnicowane wymagania dotyczące kwalifikacji osób, które mają zajmować się zawodowo rachunkowością, uczelnie muszą zastanowić się nad udoskonaleniem tych programów w celu sprostania wymaganiom przyszłych pracodawców. Wymaga to pewnej diagnozy programów kształcenia w zakresie rachunkowości na uczelniach. 
Do analizy w sposób celowy wybrano dwie uczelnie publiczne, w których liczba godzin oraz treści poszczególnych przedmiotów z rachunkowości na studiach pierwszego stopnia są bardzo zróżnicowane. Sprzyja to pytaniu: Czy osoby kończące takie studia na dwóch różnych uczelniach mogą uzyskać zbliżone kwalifikacje zawodowe?

Podstawowym celem artykułu jest porównanie i ocena wybranych elementów programów kształcenia w zakresie rachunkowości wybranych dwóch uczelni publicznych w Polsce.

W pierwszej części artykułu porównano efekty kształcenia osiągane w ramach przedmiotów kierunkowych i specjalnościowych z zakresu rachunkowości, realizowanych na Uniwersytecie Ekonomicznym w Poznaniu oraz w Państwowej Wyższej Szkole Zawodowej w Głogowie. Analizie zostały poddane formy przekazywania wiedzy, liczba godzin przypadająca na przedmiot oraz efekty kształcenia uzyskane w postaci wiedzy i umiejętności. Ostatni rozdział artykułu został poświęcony porównaniu kompetencji społecznych możliwych do uzyskania przez studentów podczas realizacji zajęć z wybranych do analizy przedmiotów.

W części teoretycznej artykułu wykorzystano metody opisowe, natomiast w części badawczej posłużono się studium przypadku. Wykorzystano również metody analizy porównawczej.

\section{POJĘCIE PROGRAMU KSZTAŁCENIA NA UCZELNI}

Program kształcenia dla określonego kierunku studiów, poziomu i profilu kształcenia obejmuje opis zakładanych efektów kształcenia oraz program studiów (art. 2, art. 4 Rozporządzenia Ministra Nauki i Szkolnictwa Wyższego z dnia 26 września 2017 r. w sprawie warunków prowadzenia studiów. DZU z 2017 r., poz. 1596). Program ten powinien uwzględniać uniwersalne charakterystyki studiów pierwszego stopnia oraz drugiego stopnia, w tym wybrane efekty kształcenia właściwe dla obszaru (lub obszarów) kształcenia, do którego został przyporządkowany kierunek studiów. Uczelnia określa również formę studiów, w jakiej będzie prowadzić kształcenie na danym kierunku oraz liczbę semestrów i liczbę punktów ECTS konieczną do uzyskania kwalifikacji odpowiadających poziomowi kształcenia. Opracowuje moduły zajęć oraz przypisuje do nich (Kuzior i Rowińska 2016):

- efekty kształcenia,

- treści programowe,

- formy i metody kształcenia,

- możliwe do uzyskania punkty ECTS.

Następnie uczelnia przygotowuje sposoby weryfikacji i oceny osiągania przez studenta zakładanych efektów kształcenia. Tworzy plan studiów, przypisując moduły kształcenia do poszczególnych semestrów. Ponadto wskazuje łączną liczbę punktów ECTS, którą student musi uzyskać w ramach zajęć wymagających bezpośredniego udziału nauczycieli akademickich i studentów. Określa również wymiar, zasady i formę odbywania praktyk zawodowych dla kierunku studiów o profilu praktycznym, w przypadku kierunku studiów o profilu ogólnoakademickim - jeżeli program kształcenia na tych studiach przewiduje praktyki, a także liczbę punktów ECTS, którą student musi uzyskać w ramach tych praktyk. Program studiów zawiera opis procesu kształcenia prowadzącego do uzyskania zakładanych efektów kształcenia dla kierunku studiów, poziomu i profilu kształcenia. 


\section{OPIS PRÓBY BADAWCZEJ}

$\mathrm{Na}$ potrzeby artykułu dokonano porównania i oceny wybranych elementów programu kształcenia w odniesieniu do trzech przedmiotów z zakresu rachunkowości na studiach stacjonarnych pierwszego stopnia na kierunku finanse i rachunkowość biznesu na Wydziale Zarządzania Uniwersytetu Ekonomicznego w Poznaniu oraz na kierunku finanse i rachunkowość w Instytucie Ekonomicznym Państwowej Wyższej Szkoły Zawodowej w Głogowie. Dobór uczelni oraz realizowanych przedmiotów był celowy. Uniwersytet Ekonomiczny w Poznaniu znalazł się na trzecim miejscu rankingu „Perspektywy 2017”1 w kategorii najlepsze uczelnie ekonomiczne (25. miejsce). Państwowa Wyższa Szkoła Zawodowa w Głogowie nie była notowana w tym rankingu, niemniej prowadzi zbliżony tematycznie kierunek studiów pierwszego stopnia. Oceniane przedmioty są typowymi przedmiotami, które są realizowane na uczelniach o profilu ekonomicznym w Polsce. Porównano, w odniesieniu do tych przedmiotów, takie elementy programu nauczania, jak: efekty kształcenia możliwe do uzyskania przez studenta w ramach danego przedmiotu, liczbę godzin i punktów ECTS oraz ich treści programowe.

\section{ZAKRES WIEDZY I UMIEJĘTNOŚCI OFEROWANYCH W RAMACH WYBRANYCH PRZEDMIOTÓW Z ZAKRESU RACHUNKOWOŚCI NA ANALIZOWANYCH UCZELNIACH}

Punktem wyjścia do oceny programów kształcenia, w odniesieniu do przedmiotów z zakresu rachunkowości, na analizowanych uczelniach było porównanie efektów kształcenia z zakresu wiedzy i umiejętności uzyskiwanych przez absolwentów pierwszego stopnia studiów stacjonarnych.

Do analizy wybrano przedmioty zarówno z modułu kierunkowego, jak i specjalnościowego, które występowały na obu uczelniach pod taką samą lub zbliżoną nazwą, sugerującą zbieżny zakres realizowanych treści programowych. Należą do nich:

- podstawy rachunkowości,

- sprawozdawczość (i analiza) finansowa,

- rachunkowość zarządcza i rachunek kosztów.

Porównanie efektów kształcenia dla przedmiotu kierunkowego podstawy rachunkowości przedstawiono $\mathrm{w}$ tab. 1.

Przedmiot podstawy rachunkowości, zarówno na Uniwersytecie Ekonomicznym w Poznaniu, jak i w Państwowej Wyższej Szkoły Zawodowej w Głogowie, należy do grupy przedmiotów kierunkowych. W przypadku uczelni poznańskiej liczba godzin dydaktycznych obejmuje 30 godzin wykładów i 30 godzin ćwiczeń, natomiast na uczelni głogowskiej wynosi ona odpowiednio 15 i 30 godzin. Nakład pracy własnej studenta, poza uczestnictwem w zajęciach prowadzonych przez nauczyciela akademickiego na uczelni poznańskiej, wynosi 90 godzin, a na drugiej uczelni - 80 godzin. Zakres wiedzy i umiejętności studenta

\footnotetext{
${ }^{1}$ Tworząc ranking „Perspektywy 2017”, brano pod uwagę czynniki takie, jak: absolwenci na rynku pracy, prestiż, siła naukowa, warunki kształcenia, innowacyjność, umiędzynarodowienie studiów. Dokładne informacje na temat zastosowanej metodologii znajdują się na stronie: www.perspektywy.pl/RSW2017/.
} 
uczelni w Głogowie mimo mniejszej liczby godzin jest większy, gdyż posiada on wiedzę i umiejętności z zakresu sprawozdawczości finansowej jednostki, zna konstrukcję sprawozdania finansowego oraz posiada umiejętność jego rozumienia.

Tabela 1. Porównanie efektów kształcenia w zakresie wiedzy i umiejętności dla przedmiotu kierunkowego podstawy rachunkowości

\begin{tabular}{|c|c|c|c|}
\hline \multicolumn{2}{|l|}{$\begin{array}{c}\text { Uniwersytet Ekonomiczny w Poznaniu } \\
\text { Wydział Zarządzania } \\
\text { finanse i rachunkowość biznesu } \\
\end{array}$} & \multicolumn{2}{|c|}{$\begin{array}{c}\text { Państwowa Wyższa Szkoła Zawodowa w Głogowie } \\
\text { Instytut Ekonomiczny } \\
\text { finanse i rachunkowość }\end{array}$} \\
\hline \multicolumn{4}{|c|}{ podstawy rachunkowości } \\
\hline wiedza - efekty kształcenia & $\begin{array}{l}\text { liczba } \\
\text { godzin } \\
\text { W/ĆW. }\end{array}$ & wiedza - efekty kształcenia & $\begin{array}{l}\text { liczba } \\
\text { godzin } \\
\text { W/ĆW. }\end{array}$ \\
\hline $\begin{array}{l}\text { Student zna zasady rachunkowości nie- } \\
\text { zbędne do ustalania wartości majątku, } \\
\text { źródeł finansowania i wyniku finansowego } \\
\text { osiąganego przez jednostkę gospodarczą } \\
\text { Student posiada wiedzę z zakresu ewi- } \\
\text { dencji operacji gospodarczych }\end{array}$ & \multirow{3}{*}{$30 / 30$} & $\begin{array}{l}\text { Student posiada wiedzę z zakresu iden- } \\
\text { tyfikowania majątku podmiotu oraz kapi- } \\
\text { tałów własnych i obcych } \\
\text { Student posiada wiedzę z zakresu prawid- } \\
\text { łowej dokumentacji księgowej } \\
\text { Student posiada wiedzę z zakresu kon- } \\
\text { strukcji sprawozdania finansowego }\end{array}$ & \multirow{3}{*}{$15 / 30$} \\
\hline umiejętności - efekty kształcenia & & umiejętności - efekty kształcenia & \\
\hline $\begin{array}{l}\text { Student interpretuje zasady ujmowania } \\
\text { operacji gospodarczych w księgach rachun- } \\
\text { kowych i przy ustalaniu wyniku finanso- } \\
\text { wego } \\
\text { Student stosuje zasady wyceny bilansowej }\end{array}$ & & $\begin{array}{l}\text { Student posiada umiejętność identyfikacji } \\
\text { operacji gospodarczych } \\
\text { Student posiada umiejętność sporządzania } \\
\text { dokumentacji księgowej } \\
\text { Student posiada umiejętność rozumienia } \\
\text { sprawozdania finansowego }\end{array}$ & \\
\hline Razem nakład pracy*/ ECTS & $150 / 6$ & Razem nakład pracy*/ ECTS & $125 / 5$ \\
\hline
\end{tabular}

W/ĆW. - liczba godzin wykładów/ćwiczeń - 45 min.

* Łączny nakład pracy studenta wyrażony w godzinach lekcyjnych, rozumiany jako udział w zajęciach, przygotowanie do zajęć, egzaminów i zaliczeń oraz praca własna z literaturą.

Źródło: opracowano na podstawie sylabusów przedmiotów dostępnych na stronach internetowych wybranych uczelni (http://ie.pwsz.glogow.pl/sylabusy/; http://www.e-sylabus.ue.poznan.pl/).

Student uczelni poznańskiej natomiast zna zasady rachunkowości oraz zasady wyceny niezbędne do ustalenia stanu aktywów i pasywów oraz wyniku finansowego. Ponadto student uczelni głogowskiej, podobnie jak poznańskiej, zna zasady ustalania wyniku finansowego, identyfikacji i ewidencji operacji gospodarczych, a także dokumentacji księgowej. Powyższe efekty kształcenia powinny być uzyskane poprzez realizację treści programowych przedstawionych w tab. 2.

Treści programowe przedmiotu podstawy rachunkowści są w pewnym zakresie zróżnicowane. Wynika to z odmiennych efektów kształcenia, które student ma uzyskać podczas realizacji tego przedmiotu. Na uczelni głogowskiej treści te są rozszerzone o zagadnienia związane ze sprawozdawczością finansową i podstawami rachunku kosztów. Problemem na uczelni głogowskiej może być brak możliwości zrealizowania tak bardzo rozbudowanych treści przedmiotu, przy mniejszej liczbie godzin wykładowych. Należy zwrócić również uwagę na to, że zarówno podstawy rachunku kosztów, jak i podstawy sprawozdawczości finansowej są zazwyczaj realizowane w ramach odrębnych przedmiotów. Ponadto na tej uczelni, w efektach kształcenia dla przedmiotu podstawy rachunkowości brakuje wiedzy i umiejętności związanych z treściami podstaw rachunku kosztów. Mniejsza 
liczba godzin dydaktycznych oraz większy zakres treści programowych wymaga od studentów uczelni głogowskiej większego nakładu pracy własnej, również poza przewidzianym w opisie przedmiotu. Należy jednak podkreślić, że zarówno studenci uczelni poznańskiej, jak i głogowskiej zdobywają podstawową wiedzę i umiejętności z zakresu rachunkowości, które są kluczowe w pracy księgowego. Stanowią one podstawę dalszego kształcenia w tej dziedzinie.

Tabela 2. Treści programowe realizowane w ramach przedmiotu podstawy rachunkowości

\begin{tabular}{|c|c|}
\hline $\begin{array}{c}\text { Uniwersytet Ekonomiczny w Poznaniu } \\
\text { Wydział Zarządzania } \\
\text { finanse i rachunkowość biznesu }\end{array}$ & $\begin{array}{c}\text { Państwowa Wyższa Szkoła Zawodowa w Głogowie } \\
\text { Instytut Ekonomiczny } \\
\text { finanse i rachunkowość }\end{array}$ \\
\hline \multicolumn{2}{|c|}{ podstawy rachunkowości } \\
\hline treści programowe & treści programowe \\
\hline $\begin{array}{l}\text { Pojęcie i normy prawne rachunkowości finansowej } \\
\text { Aktywa, pasywa, przychody, koszty } \\
\text { Zasady rachunkowości } \\
\text { Księgi rachunkowe i konto księgowe } \\
\text { Pojęcie, zasady ewidencji i wyceny: rzeczowych } \\
\text { aktywów trwałych, wartości niematerialnych i praw- } \\
\text { nych, inwestycji, rozrachunków, materiałów i towa- } \\
\text { rów, produkcji, kapitału własnego } \\
\text { Zasady ustalania wyniku finansowego }\end{array}$ & $\begin{array}{l}\text { Rachunkowość jako system ewidencji gospodarczej } \\
\text { Majątek i źródła jego finansowania } \\
\text { Operacje gospodarcze } \\
\text { Zasady ewidencji operacji gospodarczych } \\
\text { Podstawy rachunku kosztów } \\
\text { Podstawy sprawozdawczości finansowej }\end{array}$ \\
\hline
\end{tabular}

Źródło: opracowano na podstawie sylabusów przedmiotów dostępnych na stronach internetowych analizowanych uczelni (http://ie.pwsz.glogow.pl/sylabusy/; http://www.e-sylabus.ue.poznan.pl/).

Kolejnymi przedmiotami, które poddano analizie porównwczej na obu uczelniach są przedmioty kierunkowe z zakresu sprawozdawczości finansowej. Efekty kształcenia dla przedmiotów kierunkowych sprawozdawczość finansowa oraz sprawozdawczość i analiza finansowa zostały przedstawione w tab. 3 .

Przedmioty sprawozdawczość finansowa oraz sprawozdawczość i analiza finansowa na obu wybranych uczelniach są przedmiotami kierunkowymi, a ich wymiar godzinowy wynosi 45 godzin dydaktycznych (15 godzin wykładów i 30 godzin ćwiczeń). Różnią się za to łącznym nakładem pracy studenta - na uczelni z Poznania jest on większy i wynosi 152 godziny, natomiast na uczelni z Głogowa - 125 godzin. Wiąże się z tym mniejsza liczba punktów ECTS w przypadku szkoły głogowskiej. W przypadku absolwentów Uniwersytetu Ekonomicznego w Poznania brakuje w efektach kształcenia podstawowych treści niezbędnych do wstępnej analizy sprawozdań finansowych, mimo że elementy analizy pojawiają się w obszarze umiejętności. Trudno stwierdzić, czy student jest w stanie nabyć takie umiejętności po analizie treści programowych tego przedmiotu. Należy zwrócić uwagę na to, że na poznańskiej uczelni analiza finansowa występuje jako odrębny przedmiot. Absolwent Wyższej Szkoły Zawodowej w Głogowie, poza wiedzą i umiejętnościami związanymi ze sporządzaniem sprawozdań finansowych, zna metody analizy i potrafi ją przeprowadzić, co jest zgodne z nazwą przedmiotu. To, czy możliwe jest przekazanie wiedzy i umiejętności z zakresu sprawozdawczości oraz analizy finansowej w wyczerpujący sposób w podanym wymiarze godzin, wymaga oceny studentów po określonym cyklu kształcenia. 
Tabela 3. Porównanie efektów kształcenia w zakresie wiedzy i umiejętności dla przedmiotów kierunkowych sprawozdawczość finansowa oraz sprawozdawczość i analiza finansowa

\begin{tabular}{|c|c|c|c|}
\hline \multicolumn{2}{|c|}{$\begin{array}{l}\text { Uniwersytet Ekonomiczny w Poznaniu } \\
\text { Wydział Zarządzania } \\
\text { finanse i rachunkowość biznesu }\end{array}$} & \multicolumn{2}{|c|}{$\begin{array}{c}\text { Państwowa Wyższa Szkoła Zawodowa w Głogowie } \\
\text { Instytut Ekonomiczny } \\
\text { finanse i rachunkowość }\end{array}$} \\
\hline \multicolumn{2}{|l|}{ sprawozdawczość finansowa } & \multicolumn{2}{|c|}{ sprawozdawczość i analiza finansowa } \\
\hline wiedza - efekty kształcenia & $\begin{array}{l}\text { liczba } \\
\text { godzin } \\
\text { W/ĆW. }\end{array}$ & wiedza - efekty kształcenia & $\begin{array}{l}\text { liczba } \\
\text { godzin } \\
\text { W/ĆW. }\end{array}$ \\
\hline $\begin{array}{l}\text { 1. Student wskazuje elementy sprawoz- } \\
\text { dania finansowego i ich zawartość } \\
\text { informacyjną } \\
\text { 2. Student dobiera metody wyceny bi- } \\
\text { lansowej do poszczególnych element- } \\
\text { tów bilansu } \\
\text { 3. Student zna zasady sporządzania } \\
\text { sprawozdania finansowego }\end{array}$ & $15 / 30$ & $\begin{array}{l}\text { 1. Student zna zakres, metody i pro- } \\
\text { cedury sporządzania sprawozdania fi- } \\
\text { nansowego } \\
\text { 2. Student ma wiedzę o normach i stan- } \\
\text { dardach sprawozdawczości finansowej } \\
\text { 3. Student zna zakres, metody i pro- } \\
\text { cedury realizacji analizy finansowej }\end{array}$ & $15 / 30$ \\
\hline umiejętności - efekty kształcenia & & umiejętności - efekty kształcenia & \\
\hline $\begin{array}{l}\text { 1. Student przeprowadza wycenę skład- } \\
\text { ników sprawozdawczych bilansowych } \\
\text { na dzień wyceny bilansowej. } \\
\text { 2. Student dobiera dane potrzebne do } \\
\text { sporządzenia sprawozdania finanso- } \\
\text { wego } \\
\text { 3. Student wstępnie analizuje dane za- } \\
\text { warte w sprawozdaniu finansowym }\end{array}$ & & $\begin{array}{l}\text { 1. Student potrafi wykorzystać wiedzę } \\
\text { teoretyczną do sporządzania popraw- } \\
\text { nych merytorycznie i formalnie spra- } \\
\text { wozdań finansowych } \\
\text { 2. Student potrafi analizować przebieg } \\
\text { i wyniki procesów gospodarczych na } \\
\text { podstawie sprawozdania finansowego } \\
\text { 3. Student potrafi dostosować sprawoz- } \\
\text { danie finansowe do obowiązujących } \\
\text { norm i standardów }\end{array}$ & \\
\hline Razem nakład pracy*/ ECTS & $152 / 6$ & Razem nakład pracy*/ ECTS & $125 / 5$ \\
\hline
\end{tabular}

Objaśnienia oznaczeń zob. tab. 1.

Źródło: opracowano na podstawie sylabusów przedmiotów dostępnych na stronach internetowych wybranych uczelni (http://ie.pwsz.glogow.pl/sylabusy/; http://www.e-sylabus.ue.poznan.pl/).

W tabeli 4 przedstawiono treści programowe realizowane w ramach przedmiotów sprawozdawczość finansowa oraz sprawozdawczość i analiza finansowa.

W odniesieniu do treści programowych z przedmiotów przedstawionych w tab. 4 wynika, że studenci uczelni z Poznania realizują tematy z zakresu badania sprawozdania finansowego oraz międzynarodowych standardów sprawozdawczości finansowej. Tego rodzaju zagadnienia nie występują w programie przedmiotu na uczelni głogowskiej.

W programie tej uczelni $z$ kolei pojawiają się 3 tematy związane $z$ analizą finansową, których treści nie ma uczelnia poznańska. Należy jednak wspomnieć, że Uniwersytet Ekonomiczny w Poznaniu w programie studiów ma odrębny przedmiot z zagadnienami analizy finansowej. Nie sposób porównywać efektów kształcenia osiąganych $w$ ramach całego oddzielnego przedmiotu na Uniwersytecie Ekonomicznym w Poznaniu (30 godzin wykładów i 30 godzin ćwiczeń) z efektami uzyskanymi po zrealizowaniu 3 tematów w Wyższej Szkole Zawodowej w Głogowie (5 godzin wykładów i 10 godzin ćwiczeń). W zakresie sprawozdawczości finansowej, poza podstawowymi pojęciami, wiedza i umiejętności studentów są rozwijane w innych kierunkach - na uczelni poznańskiej są realizowane zagadnienia dotyczące skonsolidowanych sprawozdań finansowych, a na uczelni głogowskiej rozszerzono tematy związane $z$ analizą finansową. 
Tabela 4. Treści programowe dla przedmiotów sprawozdawczość finansowa oraz sprawozdawczość i analiza finansowa

\begin{tabular}{|c|c|}
\hline \multicolumn{1}{|c|}{$\begin{array}{c}\text { Uniwersytet Ekonomiczny w Poznaniu } \\
\text { Wydział Zarządzania } \\
\text { finanse i rachunkowość biznesu }\end{array}$} & \multicolumn{1}{c|}{$\begin{array}{c}\text { Państwowa Wyższa Szkoła Zawodowa w Głogowie } \\
\text { Instytut Ekonomiczny } \\
\text { finanse i rachunkowość }\end{array}$} \\
\hline \multicolumn{1}{|c|}{ treści programozdawczość finansowa } & \multicolumn{1}{c|}{ sprawozdawczość i analiza finansowa } \\
\hline \multicolumn{1}{|c|}{ treści programowe }
\end{tabular}

Źródło: opracowano na podstawie sylabusów przedmiotów dostępnych na stronach internetowych wybranych uczelni (http://ie.pwsz.glogow.pl/sylabusy/; http://www.e-sylabus.ue.poznan.pl/).

Efekty kształcenia dla przedmiotów specjalnościowych związanych z rachunkowością zarządczą i rachunkiem kosztów zostały przedstawione w tab. 5.

W przypadku przedmiotów specjalnościowych związanych z rachunkowością zarządczą i rachunkiem kosztów występują znaczne różnice - zarówno pod względem godzin, jak i w osiąganych efektach kształcenia. Na uczelni z Poznania realizowany jest przedmiot podstawy rachunku kosztów i rachunkowości zarządczej w wymiarze 30 godzin wykładowych. Nie przewiduje się nakładu pracy własnej studenta, poza uczestnictwem w zajęciach. $\mathrm{Na}$ uczelni głogowskiej występują z kolei dwa odrębne przedmioty - rachunek kosztów i rachunkowość zarządcza. Są one realizowane w wymiarze po 15 godzin wykładów i 30 godzin ćwiczeń (łącznie dla obu przedmiotów i form zajęć to 90 godzin). Jednak opis efektów kształcenia w obszarach wiedzy i umiejętności w przypadku uczelni poznańskiej jest nie tylko bardziej szczegółowy niż dla obu przedmiotów na uczelni głogowskiej, ale obejmuje większy ich zakres. Czy możliwe jest przyswojenie przez studenta uczelni z Poznania wiedzy i - co jest istotne - umiejętności w ciągu 30 godzin wykładów w takim samym (bądź nawet większym) zakresie jak przez studenta uczelni z Głogowa w trakcie 30 godzin wykładów i dodatkowo 60 godzin ćwiczeń? Należałoby zbadać kompetencje studentów po zakończeniu zajęć $z$ danych przedmiotów. W tabeli 6 został przedstawiony zakres realizowanych treści programowych dla trzech analizowanych przedmiotów. 
Tabela 5. Porównanie efektów kształcenia w zakresie wiedzy i umiejętności dla przedmiotów specjalnościowych związanych z rachunkowością zarządczą i rachunkiem kosztów

\begin{tabular}{|c|c|c|c|}
\hline \multirow{2}{*}{\multicolumn{2}{|c|}{$\begin{array}{c}\text { Uniwersytet Ekonomiczny w Poznaniu } \\
\text { Wydział Zarządzania } \\
\text { finanse i rachunkowość biznesu } \\
\text { podstawy rachunku kosztów i rachunkowości } \\
\text { zarządczej }\end{array}$}} & \multicolumn{2}{|c|}{$\begin{array}{c}\text { Państwowa Wyższa Szkoła Zawodowa w Głogowie } \\
\text { Instytut Ekonomiczny } \\
\text { finanse i rachunkowość }\end{array}$} \\
\hline & & \multicolumn{2}{|c|}{ rachunek kosztów } \\
\hline wiedza - efekty kształcenia & $\begin{array}{l}\text { liczba } \\
\text { godzin } \\
\text { W/ĆW. }\end{array}$ & wiedza - efekty kształcenia & $\begin{array}{l}\text { liczba } \\
\text { godzin } \\
\text { W/ĆW. }\end{array}$ \\
\hline $\begin{array}{l}\text { 1. Student przytacza różne pojęcia kosz- } \\
\text { tów i kryteria ich klasyfikacji, a także } \\
\text { odmiany rachunku kosztów i objaśnia } \\
\text { ich znaczenie } \\
\text { 2. Student charakteryzuje metody kalku- } \\
\text { lacji i przyporządkowuje je do danego } \\
\text { typu produkcji } \\
\text { 3. Student przedstawia zasady rachunku } \\
\text { kosztów standardowych, rozróżnia szcze- } \\
\text { gólne odmiany rachunku kosztów wraz } \\
\text { z możliwościami ich wykorzystania } \\
\text { 4. Student opisuje zestaw sześciu funkcji } \\
\text { biznesowych łańcucha wartości i jego } \\
\text { rolę w rachunkowości zarządczej }\end{array}$ & \multirow{8}{*}{$30 / 0$} & $\begin{array}{l}\text { 1. Student posiada wiedzę w zakresie } \\
\text { kategorii kosztów } \\
\text { 2. Student posiada wiedzę w zakresie } \\
\text { ewidencji kosztów } \\
\text { 3. Student posiada wiedzę w zakresie } \\
\text { ustalania kosztów uzyskania przychodów } \\
\text { umiejętności - efekty kształcenia } \\
\text { 1. Student posiada umiejętności ewiden- } \\
\text { cji kosztów w układzie rodzajowym } \\
\text { i funkcjonalnym } \\
\text { 2. Student posiada umiejętności identy- } \\
\text { fikacji i rozliczania kosztów } \\
\text { 3. Student posiada umiejętności ustala- } \\
\text { nia kosztów uzyskania przychodów }\end{array}$ & $15 / 30$ \\
\hline \multirow{4}{*}{$\begin{array}{l}\text { 5. Student wyjaśnia istotę, założenia, } \\
\text { ograniczenia i warunki stosowania } \\
\text { koncepcji koszt-wolumen-zysk } \\
\text { 6. Student opisuje trzy główne czynniki } \\
\text { wpływające na cenę i modele kalku- } \\
\text { lacji cen wraz z warunkami i ogra- } \\
\text { niczeniami ich stosowania } \\
\text { 7. Student wyjaśnia, czym są ceny tran- } \\
\text { sferowe, a także warunki i cele ich } \\
\text { stosowania }\end{array}$} & & razem nakład pracy*/ ECTS & $110 / 4$ \\
\hline & & \multicolumn{2}{|l|}{ rachunkowość zarządcza } \\
\hline & & wiedza - efekty kształcenia & $\begin{array}{l}\text { liczba } \\
\text { godzin } \\
\text { W/ĆW. }\end{array}$ \\
\hline & & $\begin{array}{l}\text { 1. Student ma wiedzę o narzędziach } \\
\text { i metodach wykorzystywanych w finan- } \\
\text { sach i rachunkowości oraz możliwoś- } \\
\text { ciach zastosowania nowoczesnych } \\
\text { technologii informatycznych } \\
\text { 2. Student zna metody optymalizacyjne } \\
\text { i formalnomatematyczne oraz metody } \\
\text { wnioskowania, analiz i wyboru rozwią- } \\
\text { zań } \\
\text { 3. Student zna instytucje gospodarcze } \\
\text { i polityczne oraz społeczno-ekonomi- } \\
\text { czne wyzwania rzeczywistości }\end{array}$ & \multirow[b]{3}{*}{$15 / 30$} \\
\hline umiejętności - efekty kształcenia & & umiejętności - efekty kształcenia & \\
\hline \multirow[t]{2}{*}{$\begin{array}{l}\text { 1. Student dokonuje klasyfikacji, mierzy } \\
\text { i ewidencjonuje koszty w różnych } \\
\text { przekrojach } \\
\text { 2. Student analizuje wpływ odmiany ra- } \\
\text { chunku kosztów na wycenę produktów } \\
\text { 3. Student posługuje się różnymi meto- } \\
\text { dami rozliczania kosztów i obliczania } \\
\text { kosztu jednostkowego w zależności } \\
\text { od przyjętej metody kalkulacji } \\
\text { 4. Student dobiera szczegółową odmia- } \\
\text { nę rachunku kosztów, uwzględniając } \\
\text { charakter działalności i potrzeby za- } \\
\text { rządcze } \\
\text { 5. Student analizuje warianty decyzyjne } \\
\text { w zakresie cen, kosztów i wolumenu } \\
\text { sprzedaży, a także ich wpływ na zysk } \\
\text { przedsiębiorstwa z wykorzystaniem } \\
\text { narzędzi koncepcji CVP }\end{array}$} & & $\begin{array}{l}\text { 1. Student potrafi wykorzystać wiedzę } \\
\text { teoretyczną do opisu i analizowania } \\
\text { procesów gospodarczych i finanso- } \\
\text { wych, szczególnie w zakresie groma- } \\
\text { dzenia danych na potrzeby systemów } \\
\text { finansów i rachunkowości oraz ewi- } \\
\text { dencjonowania zdarzeń gospodar- } \\
\text { czych } \\
\text { 2. Student potrafi prognozować procesy } \\
\text { finansowe przy wykorzystaniu stan- } \\
\text { dardowych metod i narzędzi statysty- } \\
\text { cznych, ekonometrycznych oraz z dzie- } \\
\text { dziny finansów i rachunkowości } \\
\text { 3. Student prawidłowo posługuje się akta- } \\
\text { mi normatywnymi oraz obowiązują- } \\
\text { cymi regułami i standardami z zakresu } \\
\text { finansów i rachunkowości }\end{array}$ & \\
\hline & & razem nakład pracy*/ ECTS & $100 / 4$ \\
\hline
\end{tabular}


Tabela 5. Porównanie efektów kształcenia w zakresie wiedzy i umiejętności dla przedmiotów specjalnościowych związanych z rachunkowością zarządczą i rachunkiem kosztów (cd.)

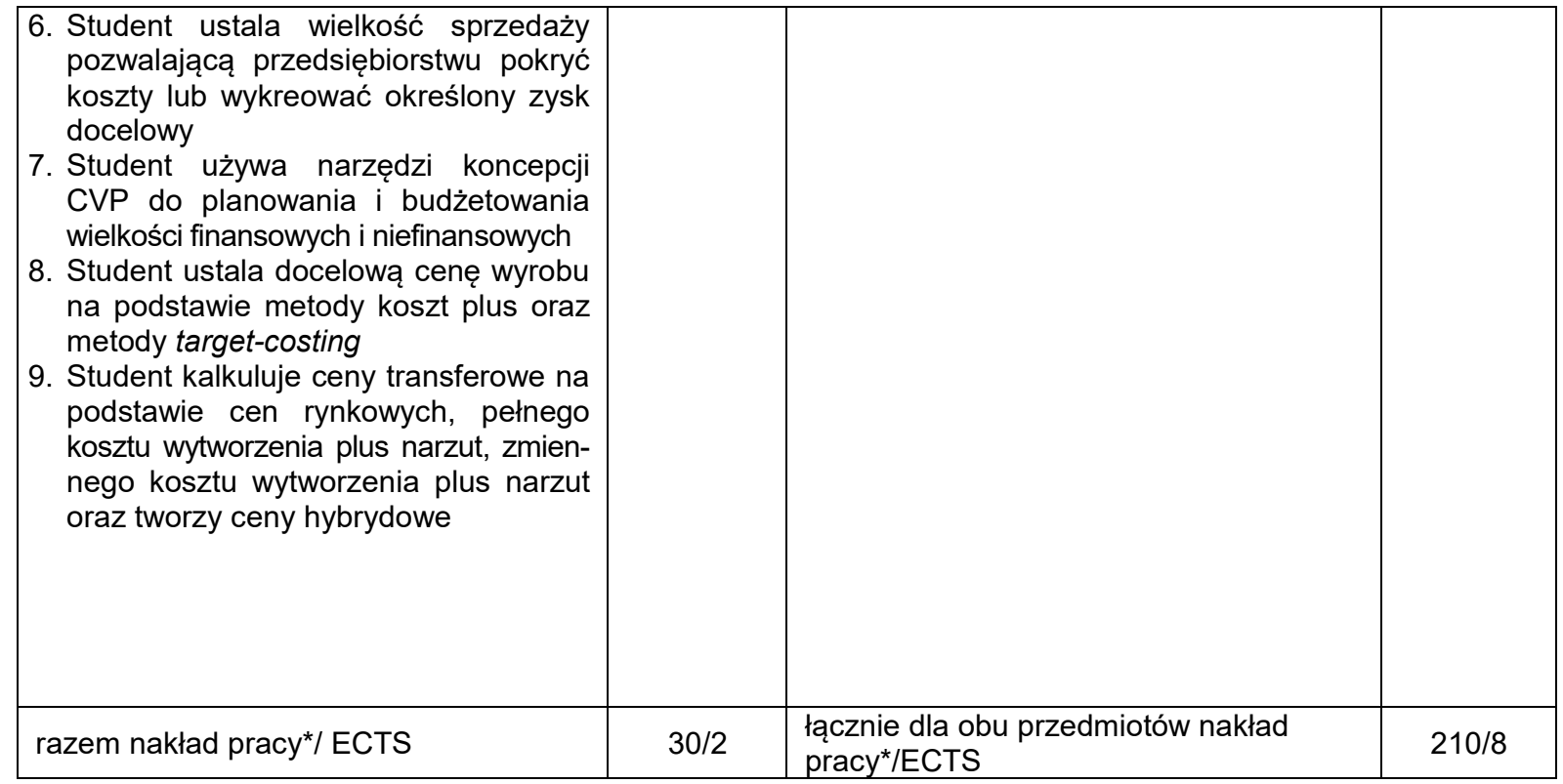

Objaśnienia oznaczeń zob. tab. 1.

Źródło: opracowano na podstawie sylabusów przedmiotów dostępnych na stronach internetowych wybranych uczelni (http://ie.pwsz.glogow.pl/sylabusy/; http://www.e-sylabus.ue.poznan.pl/).

Zwraca uwagę to, że w efektach kształcenia w obszarach wiedzy i umiejętności dla przedmiotu rachunek kosztów uczelnia z Głogowa wymienia efekty związane z kosztami uzyskania przychodów, które ze względu na złożoność obowiązującego prawa podatkowego powinny być realizowane $w$ ramach przedmiotu dotyczącego aspektów podatkowych. $Z$ kolei podany przez uczelnię z Głogowa opis efektów kształcenia w obszarze umiejętności z przedmiotu rachunkowość zarządcza prawdopodobnie nie odnosi się do tego przedmiotu, co utrudnia porównanie ich z treściami przedmiotu realizowanymi na uczelni poznańskiej.

$Z$ informacji zawartych w tab. 6 wynika, że zakres realizowanych treści programowych jest szeroki. W przypadku uczelni z Poznania niemal połowa tematów dla przedmiotu podstawy rachunku kosztów i rachunkowości zarządczej dotyczy różnych metod kalkulacji. Należy pamiętać, że uczelnia poznańska prowadzi ten przedmiot wyłącznie w formie wykładów, bez ćwiczeń. Nie gwarantuje to zdobycia umiejętności samodzielnego przeprowadzania stosownych obliczeń - student poznaje ogólny zarys teoretyczny dotyczący wymienionych metod. Uczelnia z Głogowa przedmiot rachunek kosztów realizuje również w formie ćwiczeń (rozwiązywanie przykładów i zadań). Można założyć, że skutkuje to możliwością wykorzystania przez studentów zdobytej wiedzy, którą uzyskali w trakcie wykładów. W ramach przedmiotu rachunkowość zarządcza studenci zapoznają się szczegółowo zarówno z genezą oraz podstawowymi pojęciami z rachunkowości zarządczej, jak i ze stosowanymi metodami kalkulacji kosztów. Należy wspomnieć, że przedmioty rachunek kosztów oraz rachunkowość zarządcza uczelnia z Poznania realizuje odrębnie na studiach II stopnia (rachunek kosztów jako przedmiot specjalnościowy, a rachunkowość zarządczą w ramach modułu kierunkowego). Z uwagi na różnicę poziomów studiów niemożliwe było porównanie efektów kształcenia i treści programowych z uczelnią z Głogowa. 
Tabela 6. Treści programowe dla przedmiotów specjalnościowych związanych z rachunkowością zarządczą i rachunkiem kosztów

\begin{tabular}{|c|c|}
\hline $\begin{array}{l}\text { Uniwersytet Ekonomiczny w Poznaniu } \\
\text { Wydział Zarządzania } \\
\text { finanse i rachunkowość biznesu }\end{array}$ & $\begin{array}{c}\text { Państwowa Wyższa Szkoła Zawodowa w Głogowie } \\
\text { Instytut Ekonomiczny } \\
\text { finanse i rachunkowość }\end{array}$ \\
\hline $\begin{array}{l}\text { podstawy rachunku kosztów } \\
\text { i rachunkowości zarządczej }\end{array}$ & rachunek kosztów \\
\hline treści programowe & treści programowe \\
\hline \multirow{4}{*}{$\begin{array}{l}\text { 1. Pojęcie i klasyfikacja kosztów w różnych prze- } \\
\text { krojach } \\
\text { 2. Pojęcie i odmiany rachunku kosztów } \\
\text { 3. Wycena produktów w rachunku kosztów pełnych } \\
\text { 4. Metody kalkulacji podziałowej i doliczeniowej } \\
\text { 5. Wycena produktów w rachunku kosztów zmien- } \\
\text { nych } \\
\text { 6. Rachunek kosztów standardowych } \\
\text { 7. Koszty normatywne i analiza odchyleń } \\
\text { 8. Łańcuch wartości, funkcje biznesowe i łańcuch } \\
\text { dostaw } \\
\text { 9. Koncepcja koszt-wolumen-zysk, progi rentowności } \\
\text { i docelowy zysk } \\
\text { 10. Kalkulacja cen na podstawie metody koszt plus } \\
\text { 11. Kalkulacja cen na podstawie target-costing } \\
\text { 12. Kalkulacja cen transferowych na podstawie cen } \\
\text { rynkowych, pełnego kosztu wytworzenia plus } \\
\text { narzut, zmiennego kosztu wytworzenia plus } \\
\text { narzut }\end{array}$} & $\begin{array}{l}\text { 1. Istota i kryteria klasyfikacji kosztów } \\
\text { 2. Układy ewidencyjne kosztów } \\
\text { 3. Metody kalkulacji } \\
\text { 4. Koszty uzyskania przychodów } \\
\text { 5. Przykłady i zadania sytuacyjne }\end{array}$ \\
\hline & rachunkowość zarządcza \\
\hline & treści programowe \\
\hline & $\begin{array}{l}\text { 1. Zarys historyczny rachunkowości zarządczej. Przed- } \\
\text { miot i zadania rachunkowości zarządczej. Zadania } \\
\text { i cele rachunkowości zarządczej i finansowo- } \\
\text {-księgowej. Odbiorcy rachunkowości finansowej i za- } \\
\text { rządczej. Rachunek decyzyjny a rachunek spra- } \\
\text { wozdawczy. Merytoryczne znaczenie pojęć: wartość, } \\
\text { koszt, wydatek } \\
\text { 2. Kryteria klasyfikacji kosztów. Kryteria klasyfikacji } \\
\text { kosztów dla celów sprawozdawczych. Kryteria } \\
\text { klasyfikacji kosztów dla celów decyzyjnych. Kryteria } \\
\text { klasyfikacji kosztów dla celów kontrolnych. Zacho- } \\
\text { wanie się kosztów w zależności od wielkości pro- } \\
\text { dukcji. Koszty stałe i zmienne } \\
\text { 3. Rachunek kosztów pełnych. Rachunek kosztów } \\
\text { zmiennych. Marża pokryć finansowych } \\
\text { 4. Krótkoterminowy rachunek kosztów. Wielostopniowy } \\
\text { i wieloblokowy rachunek wyników. Analiza progu } \\
\text { rentowności. Zastosowania analizy progu ren- } \\
\text { towności. Marża bezpieczeństwa. Analiza wraż- } \\
\text { liwości progu rentowności. Wyznaczanie krytycznych } \\
\text { punktów cen i kosztów } \\
\text { 5. Informacje o kosztach i wynikach w podejmowaniu } \\
\text { decyzji. Wybór asortymentu produkcji. Wybór między } \\
\text { wytwarzaniem a zakupem produktu. Wybór sposobu } \\
\text { wykorzystania wolnych mocy produkcyjnych } \\
\text { 6. Rachunek kosztów działań (ABC). Identyfikacja } \\
\text { procesów i działań. Kalkulacja kosztów działań } \\
\text { i produktów. Pomiar kosztów i wyników klientów }\end{array}$ \\
\hline
\end{tabular}

Źródło: opracowano na podstawie sylabusów przedmiotów dostępnych na stronach internetowych wybranych uczelni (http://ie.pwsz.glogow.pl/sylabusy/; http://www.e-sylabus.ue.poznan.pl/).

Jak pokazano na przykładach, w ramach podobnych przedmiotów, realizowanych na tych samych kierunkach i poziomach studiów przez wybrane uczelnie, student uzyskuje odmienne efekty kształcenia w obszarach wiedzy i umiejętności. Co więcej, różne są wymiary godzin i formy zajęć. Proces uzyskiwania efektów kształcenia zależnie od uczelni wymaga od studenta określonego nakładu pracy własnej. Nie zawsze kompensuje to mniejszą liczbę godzin zajęć z udziałem nauczyciela akademickiego. 


\section{OCENA ZAKRESU KOMPETENCJI SPOKECZNYCH MOŻLIWYCH DO UZYSKANIA W RAMACH WYBRANYCH PRZEDMIOTÓW Z ZAKRESU RACHUNKOWOŚCI NA ANALIZOWANYCH UCZELNIACH}

Kompetencje społeczne najczęściej opisuje się jako złożone umiejętności umożliwiające radzenie sobie w sposób efektywny w określonych sytuacjach społecznych. Są one niezbędne do nawiązywania i utrzymywania relacji interpersonalnych (Nadolna 2011; Smółka 2016). Kompetencje te są trzecią, obok wiedzy i umiejętności, grupą efektów kształcenia opisaną w polskiej ramie kwalifikacji, w związku z czym uczelnie wyższe mają obowiązek uwzględniać je w tworzonych programach kształcenia.

Jagodziński (2013) w swojej pracy podjął próbę stworzenia sylwetki absolwenta idealnego, opartej na kompetencjach społecznych. Według tego autora absolwenta powinny cechować:

- świadomość poziomu posiadanej wiedzy i umiejętności oraz potrzeba dokształcania zawodowego i rozwoju osobistego;

- umiejętność samooceny kompetencji;

- chęć posiadania wiedzy z różnych dziedzin przejawiająca się wyznaczaniem kierunków własnego rozwoju i samodoskonalenia;

- rozwijanie kompetencji poznawczych i otwartość na otaczający świat;

- innowacyjność i elastyczność, zdolność przystosowywania się do dynamicznego rynku pracy dzięki solidnym podstawom w postaci posiadanej wiedzy ogólnej i specjalistycznej;

- umiejętność efektywnego wykorzystywania nowoczesnych technologii w procesie rozwoju własnych kompetencji, bycie częścią społeczeństwa informacyjnego;

- predyspozycje do wnioskowania na podstawie zjawisk społecznych: politycznych, ekonomicznych, prawnych, kulturowych.

W celu sprawdzenia, czy w ramach wybranych przedmiotów kierunkowych i specjalnościowych, realizowanych przez Uniwersytet Ekonomiczny w Poznaniu oraz Państwową Wyższą Szkołę Zawodową w Głogowie, absolwenci uzyskują efekty kształcenia w obszarze kompetencji społecznych zgodne $z$ sylwetką absolwenta idealnego $w$ tym zakresie zestawiono osiągane efekty kształcenia na obu wspomnianych uczelniach w tab. 7.

$\mathrm{Na}$ podstawie danych przedstawionych w tab. 7 można stwierdzić, że najczęściej wymienianymi kompetencjami społecznymi są: umiejętność zdobywania wiedzy i doskonalenia posiadanych umiejętności, rozumienie konieczności stałego zwiększania kompetencji, myślenie w sposób kreatywny i przedsiębiorczy oraz umiejętność pracy w grupie. Zawierają się one w typowej sylwetce absolwenta studiów wyższych. W przypadku przedmiotu podstawy rachunku kosztów i rachunkowości zarządczej, prowadzonego na uczelni poznańskiej, sylabus wskazuje, że student potrafi rozwiązywać problemy dotyczące kalkulacji kosztów wytworzenia produktów na podstawie znanych mu modeli rachunku kosztów. Przedmiot jest prowadzony w czasie 30 godzin wykładowych, bez ćwiczeń. Brakuje informacji o sposobie prowadzenia wykładu, jednak można wątpić w to, czy przekazując wyłącznie wiedzę teoretyczną, student nabędzie umiejętność rozwiązywania problemów z tej dziedziny. Ponadto większość zapisów efektów kształcenia w odniesieniu do tego przedmiotu dotyczy nie kompetencji społecznych, a raczej umiejętności studenta. Podobne zastrzeżenie można mieć w odniesieniu do tych kompetencji w zakresie efektów kształcenia w przypadku przedmiotu sprawozdawczość finansowa realizowanego na tej uczelni. 
Tabela 7. Efekty kształcenia w obszarze kompetencji społecznych zdobywane przez studentów analizowanych uczelni w ramach wybranych przedmiotów kierunkowych i specjalnościowych

\begin{tabular}{|c|c|c|}
\hline \multirow[t]{2}{*}{ Przedmiot } & $\begin{array}{c}\text { Uniwersytet Ekonomiczny w Poznaniu } \\
\text { Wydział Zarządzania } \\
\text { finanse i rachunkowość biznesu }\end{array}$ & $\begin{array}{c}\text { Państwowa Wyższa Szkoła Zawodowa } \\
\text { w Głogowie } \\
\text { Instytut Ekonomiczny } \\
\text { finanse i rachunkowość }\end{array}$ \\
\hline & \multicolumn{2}{|c|}{ efekty kształcenia - kompetencje społeczne } \\
\hline $\begin{array}{l}\text { Podstawy } \\
\text { rachunkowości }\end{array}$ & $\begin{array}{l}\text { Student identyfikuje problemy związane } \\
\text { z prowadzeniem rachunkowości i jest } \\
\text { otwarty na konieczność ciągłego dosko- } \\
\text { nalenia wiedzy i umiejętności }\end{array}$ & $\begin{array}{l}\text { Student rozumie potrzebe podnoszenia } \\
\text { poziomu wiedzy w zakresie wykonywania } \\
\text { zawodu księgowego } \\
\text { Student prawidłowo identyfikuje i rozstrzyga } \\
\text { dylematy zawodu księgowego } \\
\text { Student potrafi myśleć i działać kreaty- } \\
\text { wnie }\end{array}$ \\
\hline $\begin{array}{l}\text { Sprawozdawczość } \\
\text { finansowa / } \\
\text { sprawozdawczość } \\
\text { i analiza finansowa }\end{array}$ & $\begin{array}{l}\text { Student identyfikuje problemy związane ze } \\
\text { sporządzaniem sprawozdań finansowych } \\
\text { i podejmuje dyskusję na ich temat } \\
\text { Student wyraża sądy na temat zawartości } \\
\text { sprawozdań finansowych }\end{array}$ & $\begin{array}{l}\text { Student, działając w grupie, zarządza } \\
\text { procesem sporządzania sprawozdania } \\
\text { finansowego } \\
\text { Student potrafi skoordynować prace na } \\
\text { sprawozdaniem finansowym i zbadać } \\
\text { poprawność jego sporządzenia } \\
\text { Student, działając samodzielnie, potrafi } \\
\text { uzupełnić wiedzę dotyczącą szczególnych } \\
\text { przypadków w trakcie sporządzania spra- } \\
\text { wozdania finansowego }\end{array}$ \\
\hline \multirow[t]{2}{*}{$\begin{array}{l}\text { Podstawy rachunku } \\
\text { kosztów } \\
\text { i rachunkowości } \\
\text { zarządczej* / } \\
\text { rachunek kosztów } \\
\text { oraz rachunkowość } \\
\text { zarządcza }\end{array}$} & \multirow{2}{*}{$\begin{array}{l}\text { Student identyfikuje problemy w obszarze } \\
\text { kosztów, zwłaszcza problemy z ich właściwą } \\
\text { klasyfikacją i podporządkowaną jej ewidencją } \\
\text { oraz akceptuje możliwe sposoby rozliczania } \\
\text { kosztów } \\
\text { Student rozwiązuje problemy w zakresie kalku- } \\
\text { lacji kosztów wytworzenia produktów na pod- } \\
\text { stawie znanych mu modeli rachunku kosztów } \\
\text { Student docenia ograniczenia stosowanych } \\
\text { modeli i uwzględnia ryzyko związane ze stoso- } \\
\text { waniem określonych metod ich wykorzystania } \\
\text { Student identyfikuje problemy biznesowe } \\
\text { i podejmuje wyzwanie ich rozwiązania na } \\
\text { podstawie pięciostopniowego modelu podej- } \\
\text { mowania decyzji biznesowych } \\
\text { Student uwzględnia zasady etyczne w podej- } \\
\text { mowaniu decyzji biznesowych } \\
\text { Student jest zorientowany na krytyczne ana- } \\
\text { lizowanie rzeczywistości gospodarczej w pro- } \\
\text { cesie podejmowania decyzji zarządczych }\end{array}$} & $\begin{array}{l}\text { Student potrafi wykorzystywać wiedzę } \\
\text { z zakresu kosztów do przygotowywania } \\
\text { informacji decyzyjnych } \\
\text { Student rozumie potrzebę ustawicznego } \\
\text { kształcenia } \\
\text { Student potrafi współpracować w grupie }\end{array}$ \\
\hline & & $\begin{array}{l}\text { Student ma krytyczno-analityczne po- } \\
\text { dejścia do wyzwań decyzyjnych } \\
\text { Student dostrzega i prawidłowo rozstrzy- } \\
\text { ga dylematy związane z wykonywaniem } \\
\text { zawodu związanego z finansami i rachun- } \\
\text { kowością } \\
\text { Student myśli i działa w sposób przed- } \\
\text { siębiorczy }\end{array}$ \\
\hline
\end{tabular}

*Oznaczono przedmioty realizowane wyłącznie w formie wykładów, bez ćwiczeń.

Źródło: opracowano na podstawie sylabusów przedmiotów dostępnych na stronach internetowych wybranych uczelni (http://ie.pwsz.glogow.pl/sylabusy/; http://www.e-sylabus.ue.poznan.pl/).

Opisane kompetencje społeczne będą nabierać coraz większego znaczenia, dlatego konieczne jest to, aby kształcenie na każdym etapie edukacji uwzględniało je w efektach kształcenia. Obecnie szeroko dyskutowane jest dopasowanie kształcenia przez wyższe uczelnie do oczekiwań rynku pracy. Nauka na poziomie studiów ma na celu, poza przekazaniem wiedzy przedmiotowej, także kształtowanie pewnego stylu życia, postaw i wartości.

\section{PODSUMOWANIE}

Przeprowadzona ocena wybranych elementów programu kształcenia w zakresie rachunkowości wykazała, że istnieją rozbieżności między efektami kształcenia uzyskanymi w ramach standardowych przedmiotów realizowanych na studiach ekonomicznych na 
poszczególnych uczelniach. Konsekwencją tego jest zróżnicowanie treści programowych, liczby i formy godzin oraz przyznawanych punktów ECTS dla przedmiotów realizowanych w ramach ocenianych specjalności na poszczególnych uczelniach. Rozbieżności te mogą wynikać z faktu, że uczelnia poznańska na opisywanej specjalności część treści będzie realizowała na studiach drugiego stopnia. Na uczelni w Głogowie studenci nie mają takiej możliwości, gdyż uczelnia ta realizuje tylko studia pierwszego stopnia. Niemniej ze względu na możliwość przemieszczania się studentów między poszczególnymi uczelniami określonego rodzaju przedmioty powinny dawać tą samą wiedzę, umiejetnosci i kompetencje społeczne. Szczególne różnice między efektami kształcenia na analizowanych specjalnościach między uczelnią poznańską a uczelnią głogowską występują w obszarze kompetencji społecznych. Zwłaszcza na uczelni poznańskiej nie zostały one jednoznacznie sformułowane. Należy podkreślić, że kompetencje te dotyczące zawodów związanych z rachunkowością są coraz bardziej pożądane na rynku pracy. Wskazuje się je bowiem jako kompetencje uniwersalne, mobilne, niezależne od zajmowanego stanowiska, stanowiące większość wymienianych przez ekspertów rynku pracy kompetencji kluczowych dla pracownika przyszłości.

\section{PIŚMIENNICTWO}

Jagodziński A. 2013. Oczekiwania pracodawców w zakresie kompetencji absolwentów wyższych uczelni. Zesz. Nauk. PWSZ Płock., Nauki Ekonomiczne 17, 123.

Kuzior A., Rowińska M. 2016. Koncepcje kształcenia na kierunku finanse i rachunkowość. Analiza rozwiązań przyjętych na polskich uczelniach. Folia Pomer. Univ. Technol. Stetin., Oeconomica 327(83)2,129-136.

Nadolna B. 2011. Wartości etyczne i zawodowe w edukacji księgowego. Folia Pomer. Univ. Technol. Stetin., Oeconomica 281(63), 179-188.

Rozporządzenie Ministra Nauki i Szkolnictwa Wyższego z dnia 26 września 2017 r. w sprawie warunków prowadzenia studiów. DZU z 2017 r., poz. 1596.

Smólka P. 2016. Jak skutecznie szkolić umiejętności interpersonalne? w: Komunikowanie się. Problemy i perspektywy. Red. B. Kaczmarek, A. Kucharski, M. Stencel. Lublin, Wydaw. UMCS, 247-259.

Sylabus przedmiotowy PWSZ w Głogowie, http://ie.pwsz.glogow.pl/sylabusy/, dostęp: 10.09.2017. Sylabus przedmiotowy UE w Poznaniu, http://www.e-sylabus.ue.poznan.pl/, dostęp: 11.09.2017.

Streszczenie. Zawody związane z rachunkowością należą do zawodów przyszłości. Zapotrzebowanie na pracowników $z$ rozwiniętymi kompetencjami $w$ tej dziedzinie nadal utrzymuje się na wysokim poziomie. Zawody te wymagają profesjonalnej wiedzy i konkretnych umiejętności, które adept księgowości może uzyskać również na uniwersytecie. Obecnie uczelnie wyższe, zwłaszcza ekonomiczne, w swojej ofercie edukacyjnej mają programy edukacyjne zawierające wiele przedmiotów z zakresu rachunkowości. Podstawowym celem artykułu jest porównanie wybranych elementów programów edukacyjnych z zakresu rachunkowości z dwóch uczelni publicznych w Polsce. Pierwsza część artykułu porównuje efekty kształcenia osiągnięte na głównych i specjalistycznych przedmiotach z zakresu rachunkowości prowadzonej na Uniwersytecie Ekonomicznym w Poznaniu i w Państwowej Wyższej Szkole w Głogowie. Analiza objęła formy przekazywania wiedzy, liczbę godzin przypadających na przedmiot i uzyskane efekty kształcenia studenta w zakresie jego wiedzy i umiejętności. Osobny rozdział poświęcono porównaniu możliwych do uzyskania przez studenta kompetencji społecznych, które są podane w sylabusach analizowanych uczelni. W części teoretycznej wykorzystano metody opisowe, natomiast w części badawczej wykorzystano case study. 
